MARIO LERENA

https://orcid.org/0000-0001-6000-3041

mlerena@conservatoriobilbao.com

Conservatorio J. C. de Arriaga, Bilbao

\title{
La virilidad vulnerable de un héroe modernista (1914-1918): música, ornamento y "seducción” en torno a Usandizaga
}

\section{The Vulnerable Virility of a Modernist Hero (1914-1918): Usandizaga's Music, Ornament and "Seduction"}

El éxito de la zarzuela Las golondrinas (1914), de José María Usandizaga y Gregorio Martínez Sierra (antifaz literario de María Lejárraga), marcó un hito en la escena lírica española, en una coyuntura de especial dinamismo artístico y cruciales transformaciones socioculturales que implicaron un cuestionamiento de los roles de género tradicionales. El presente trabajo rastrea las controversias de género implícitas en los discursos que apuntalaron la fama de Usandizaga como ídolo musical del momento, así como en las críticas que discutieron su deriva estética hacia un "modernismo" considerado decadente y veladamente "afeminado". Para ello, el análisis de textos en prensa y otras publicaciones contemporáneas se confronta con la imagen pública del compositor, junto con algunas evidencias biográficas y dramatúrgicas. Las contradicciones detectadas entre los requisitos canónicos presupuestos a un adalid del teatro lírico nacional y la realidad de condicionantes e inquietudes personales iluminan ciertas mistificaciones en la recepción de su legado.

Palabras clave: Modernismo, Decadentismo, zarzuela, ópera, música, España, estudios de género, Usandizaga, Martínez Sierra, 1914.

The success of the zarzuela Las golondrinas (1914), by José María Usandizaga and Gregorio Martínez Sierra (his wife, María Lejárraga, actually wrote the text), marked a milestone in Spanish stage music, in a context of artistic dynamism and crucial socio-cultural transformations that involved questioning traditional gender roles. This article traces the gender controverses implicit in the discourses that underpinned Usandizaga's fame as a musical icon of the time, as well as in the reviews that discussed his aesthetic leanings towards a "modernism" considered decadent and subtly "effeminate". To this effect, the analysis of press articles and other contemporary publications is contrasted with the composer's public image, together with certain biographical and dramaturgical evidence. The contradictions detected between the surmised canonical requirements of an advocate for Spanish musical theatre and the reality of personal constraints and concerns shed light on certain mystifications in the reception of his works.

Keywords: Modernism, Decadent movement, zarzuela, opera, music, Spain, gender studies, Usandizaga, Martínez Sierra, 1914. 


\section{Una encrucijada histórica: modernidad, "feminismo" y música}

El triunfal estreno del "drama lírico" Las golondrinas en el Circo Price de Madrid, el 5 de febrero de 1914, marcó el arranque de un período de especial efervescencia en la escena lírica española y convirtió a su autor, José María Usandizaga (San Sebastián, 1887-1915), en el ídolo musical del momento ${ }^{1}$. Lo avalaban un libreto del emergente dramaturgo Gregorio Martínez Sierra (escrito, en realidad, por su mujer, María Lejárraga) y las voces estelares del barítono Emilio Sagi Barba y su embarazadísima esposa, la soprano Luisa Vela.Tras él, otra serie de títulos de inusitada ambición y envergadura como Maruxa, de AmadeoVives, La flor del agua, de Conrado del Campo, Margot, de Turina, y La vida breve de Manuel de Falla fueron presentados ese mismo año en el recién reinaugurado Teatro de la Zarzuela. Les siguieron, en 1915, Mirentxu, de Jesús Guridi (estrenada en el País Vasco cinco años atrás), Becqueriana, de María Rodrigo, y la más iconoclasta El amor brujo, de Falla, con libreto del propio Martínez Sierra. El teatro lírico español experimentaba así una ilusionante renovación de sus parámetros formales y expresivos, conjurando un endémico sentimiento de supuesta decadencia, acentuado tras la crisis nacional del $98^{2}$.

En realidad, este súbito florecimiento era expresión de un proceso más amplio de modernización que el país atravesó en una tardía belle époque, a lo largo de la segunda década del siglo. Pese a su neutralidad oficial, el estallido de la Primera Guerra Mundial ese mismo verano de 1914 marcaría, de hecho, un hito historiográfico crucial también para España, inmersa en una acelerada "transición a la modernidad"3. En el plano intelectual, se ha hablado incluso de una "Generación de 1914", cuyos protagonistas, con Ortega y Gasset a la cabeza, acentuaron los anhelos regeneracionistas y europeizantes de la generación anterior, encauzándolos en un mayor racionalismo y sentido pragmático. En el terreno artístico y literario, el Modernismo ${ }^{4}$ finisecular perdería su hegemonía en favor de una

\footnotetext{
${ }^{1}$ Jesús M. ${ }^{a}$ de Arozamena: Joshemari Usandizaga y la bella época donostiarra, San Sebastián, Gráficas Izarra, 1969, pp. 242-265. Otras fuentes adelantan un día la fecha de estreno, por error.

${ }^{2}$ Mario Lerena: "Madrid brillante': modernismo y vanguardia de una década prodigiosa (c. 19101920)", El Teatro de Arte. Libro de las Jornadas de zarzuela 2015, Alberto González Lapuente, Alberto Honrado Pinilla (eds.), Madrid, Fundación Jacinto e Inocencio Guerrero, 2016, pp. 56-77.

${ }^{3}$ Hugo Aznar, Manuel Menéndez Alzamora: "El éxito histórico de la Generación del 14", La Generación del 14: España ante su inacabada modernidad, Hugo Aznar, Elvira Alonso Romero, Manuel Menéndez Alzamora (eds.), Madrid, Plaza y Valdés, 2016, pp. 11-21.

${ }^{4}$ Como punto de partida, adoptamos el término de Modernismo en su sentido más restrictivo aplicado comúnmente al movimiento de renovación de las artes y las literaturas hispanas que floreció en torno a las dos décadas anteriores y posteriores al cambio de siglo. Sobre su controvertida relación con el más amplio concepto anglosajón de Modernism, se han expresado, entre otros, Guido Herzovich: "Modernismo / Modernism", Vocabulario de las filosofias occidentales: diccionario de los intraducibles, Barbara Cassin (dir.), México, Siglo XXI Editores, 2018, vol. 2, pp. 1002-1010; Juan Carlos Ara Torralba: "Modernismo y 98", Ocho calas en el pensamiento literario español, Eduardo E. Salas (ed.), Sevilla, Alfar, 2012, pp. 41-66; y, en el campo musical, M. Lerena: “Madrid brillante'...", pp. 72-73. Con todo, el presente trabajo dará voz a
} 
moderada estética "novecentista" y de ocasionales "ismos" de vanguardia ${ }^{5}$. En la esfera sociopolítica, la crisis revolucionaria de 1917 sentenció el definitivo principio del fin del sistema decimonónico de la Restauración 6 .

En el plano cotidiano, una vertiente destacada de los nuevos tiempos venía asociada al creciente predicamento y visibilidad de las mujeres en distintos ámbitos de la sociedad ${ }^{7}$. De ahí que, de cara a la opinión pública, las novedades de la moda femenina emergieran también como componente esencial de la modernidad de aquellos años ${ }^{8}$. Precisamente, este protagonismo tuvo en los escenarios teatrales -y, muy frecuentemente, en el teatro musical- uno de sus principales focos de expansión, constatado ya desde finales del siglo anterior. En efecto, las intérpretes centraban no solo la mirada de sus espectadores sino también la atención de la prensa periódica, con un especial énfasis en su presencia fisica, su indumentaria y el glamur del que hacían ostentación ${ }^{9}$. Se ha señalado, de hecho, el importante papel que el vestuario a la moda jugó en la promoción y éxito internacional de la contemporánea opereta vienesa ${ }^{10}$.

Dicho fenómeno tomaría definitiva carta de naturaleza en esta segunda década del siglo por medio de exitosas estrategias de dignificación de la figura y el oficio de las artistas escénicas. Gracias a ellas, algunas cupletistas y bailarinas "frívolas" comenzaron a ser vistas no solo como objeto de escándalo, sino como encarnación de nuevos modelos de feminidad ${ }^{11}$. No obstante, la presencia activa de mujeres en la sociedad y la cultura españolas de esta época,

consideraciones dispares vertidas por la crítica y los propios artistas contemporáneos a dicho fenómeno, que evidenciaron la ambigua complejidad del ideario modernista en el momento y lugar objeto de nuestro estudio.

${ }^{5}$ Eugenio Carmona: "Vernáculo \& Moderno. Novecentismo y vanguardia en la colección del Museo de Bellas Artes de Bilbao", Novecentismo y Vanguardia (1910-1936) en la colección del Museo de Bellas Artes de Bilbao, Miren Alzuri (coord.), Bilbao, Museo de Bellas Artes, 2009, pp. 33-86.

${ }^{6}$ Carlos Serrano, Serge Salaün (eds.): Los felices años veinte: España, crisis y modernidad, Madrid, Marcial Pons, 2006, pp. 42-43.

${ }^{7}$ Susan Kirkpatrick: Mujer, modernismo y vanguardia en España (1898-1931), Jacqueline Cruz (trad.), Madrid, Cátedra, 2003, pp. 8-11.

${ }^{8}$ Sobre la compleja imbricación entre moda, sociedad de consumo y feminismo durante la belle époque, véase Nacho Moreno Segarra: Ladronas victorianas: cleptomanía y género en el origen de los grandes almacenes, s. l., Antipersona, 2017.

${ }^{9}$ Isabel Clúa: "Las joyas de la Otero: los inicios del glamour en la escena teatral de fin de siglo", Miradas sobre el cuplé en España: identidades, contextos, artistas y repertorios, Enrique Encabo (ed.), Madrid, ICCMU, 2019, pp. 79-94.

${ }^{10}$ Stefan Frey: "Going Global: The International Spread of Viennese Silver-Age Operetta", The Cambridge Companion to Operetta, Anastasia Belina, Derek B. Scott (eds.), Cambridge, Cambridge University Press, 2020, pp. 95-97. Para el caso español contemporáneo, Ignacio Jassa Haro: "Con un vals en la maleta: viaje y aclimatación de la opereta en España", Cuadernos de Música Iberoamericana, 20, 2010, p. 91.

${ }^{11}$ La actuación de las célebres Fornarina y Tórtola Valencia en el prestigioso Ateneo de Madrid (en 1911 y 1913, respectivamente) es una muestra paradigmática de este cambio de mentalidad. Véase Isabel Clúa: Cuerpos de escándalo: celebridad femenina en el fin-de-siècle, Barcelona, Icaria, 2016, pp. 132-142; Enrique Encabo Fernández: "Consuelo Vello, La Fornarina, (1884-1915): la divina erótica, la refinada sicalíptica”, Cultura de la seducción. Patricia Cifre Wibow, Manuel González de Ávila (coords.), Salamanca, 
más allá del hogar, no se limitaba ya a la esfera de la farándula, sino que se extendía, de forma aún minoritaria pero cada vez más significativa, a otros ámbitos de la vida pública. De hecho, la discreta proliferación de autoras y pensadoras en diversas plataformas de comunicación (como la citada Carmen de Burgos, Margarita Nelken o, en el terreno de la crítica musical, Matilde Muñoz) permite hablar también de un representativo grupo femenino de la Generación del $14^{12}$.

Un caso particular, para el asunto que nos atañe, era el de la autora del libreto de Las golondrinas, María de la O Lejárraga; una de las plumas teatrales más aplaudidas del momento, pero siempre oculta bajo la firma de su marido, Gregorio Martínez Sierra. El matrimonio ya había asumido un papel primordial en la promoción del Modernismo literario durante la década anterior, pero solo a partir de esta década comenzó a hacerse veladamente pública la decisiva participación de María en los escritos de Gregorio (un secreto a voces en medios artísticos $)^{13}$. Pese a las equívocas convenciones de género, el feminismo de María Lejárraga ya asomaba en sus artículos sobre "La mujer moderna en España", que entre 1915 y 1916 publicó Gregorio en un medio tan burgués y biempensante como la revista Blanco y Negro ${ }^{14}$. Sin duda, sus importantes colaboraciones con compositores de la talla de Turina, Falla y el propio Usandizaga, exigen reconocer a la autora un papel fundamental en el desarrollo de la música teatral española del siglo $\mathrm{XX}^{15}$.

Curiosamente, pocos días después del estreno de Las golondrinas, Joaquín Turina expresaba su ansiedad ante el imparable ascenso de la mujer en el campo musical, en un texto sobre "El feminismo y la música". Si bien el compositor sevillano reconocía las cotas de "refinamiento y finura" que las mujeres podían alcanzar en el terreno de la interpretación, negaba su capacidad para la creación musical, ridiculizando los, para él, estériles e insanos esfuerzos de las alumnas de la parisina Schola Cantorum, donde tanto él como Usandizaga se habían formado:

Ediciones Universidad de Salamanca, 2014, pp. 251-258. También lo fue la publicación, en 1916, de una recopilación de Confidencias de artistas (femeninas) entrevistadas por Carmen de Burgos y prologada por Ramón Gómez de la Serna. Carmen de Burgos: Confidencias de artistas, Madrid, Juan Pueyo, s. f. [1916].

${ }^{12}$ Marcia Castillo Martín: "Mujeres de la Generación del 14: una generación de precursoras", La Generación del 14: España ante su inacabada modernidad, Hugo Aznar, Elvira Alonso Romero, Manuel Menéndez Alzamora (eds.), Madrid, Plaza y Valdés, 2016, p. 99.

${ }^{13}$ Juan Aguilera Sastre: "María Lejárraga y el teatro de su época: la conquista de un público", De literatura y música: estudios sobre María Martinez Sierra, Teresa Cascudo, María Palacios (eds.), Logroño, Instituto de Estudios Riojanos, 2014, pp. 68-70; José Montero Padilla: "Gregorio Martínez Sierra y su primera comedia", Hesperia: Anuario de Filología Hispánica, 10, 2007, pp. 13-15.

${ }^{14}$ Alda Blanco: "El género como principio organizativo en la obra de María Martínez Sierra", De literatura y música: estudios sobre María Martinez Sierra, Teresa Cascudo, María Palacios (eds.), Logroño, Instituto de Estudios Riojanos, 2014, pp. 15-34.

${ }^{15}$ M. ${ }^{2}$ Luz González Peña: Música y músicos en la vida de María Lejárraga, Logroño, Instituto de Estudios Riojanos, 2009. 
Estudian la composición con mucho más ahínco que el hombre, y con la facilidad de memoria de que son capaces, amontonan fechas sobre fechas, nombres sobre nombres, cual si fueran diccionarios vivientes, y cuando llegan al fin de su carrera, y cuando su pluma casi siempre premiosa no logra trazar más que contornos banales y elucubraciones complicadas, cual si fuesen hechas con doce bolillos, entonces en la mayor de las rabietas, deciden ser eruditas y hacer críticas, analizando las obras ajenas en una disección sangrienta, como si se tratara del mal corte de una falda entravée ${ }^{16}$.

A pesar de lo inicuo de esta invectiva, resulta sumamente significativa su comparación del trabajo de dichas compositoras con una labor de costura (el encaje de bolillos), rematada por la alusión al corte y confección de una prenda a la moda. En efecto, tal y como señala Susan Kirkpatrick, las labores de aguja y ciertas artes decorativas eran a menudo la única vía que permitía a las mujeres desarrollar una creatividad afin al esteticismo modernista ${ }^{17}$; siendo el adorno corporal y del hogar apreciado como tarea idealmente femenina ${ }^{18}$. En paralelo, Turina que en pocos meses estrenaría su "comedia lírica" Margot, sobre libreto de Martínez Sierra, sin ningún éxito- encontraba una complejidad pretenciosa pero insustancial en las composiciones ("contornos banales") de sus condiscípulas. Además, el esfuerzo por emular un cerebralismo considerado típicamente masculino consumía, en su opinión, la salud de sus autoras, "pálidas y macilentas", masculinizándolas hasta el punto de poner en tela de juicio su propia categoría de género: ¿`son realmente mujeres?”, se llega a cuestionar el músico.

Como es sabido, la trágica cotidianeidad de los países combatientes en la Gran Guerra no haría sino propulsar este ascenso socio-laboral de la mujer en todos los ámbitos, dada la escasez de mano de obra masculina, ocupada o masacrada en el frente ${ }^{19}$. De este modo, las controversias en torno a la intersexualidad de los patrones de género y la conformación de un supuesto "tercer sexo" andrógino no dejarían de acrecentarse en años sucesivos, también en nuestro país $^{20}$. De hecho, pronto surgirían voces abogando por una "restauración" de la tradicional masculinidad española (pareja a la pretendida regeneración del país), o bien por una reformulación más progresista de dichos estereotipos ${ }^{21}$.

\footnotetext{
${ }^{16}$ Joaquín Turina: "El feminismo y la música", Revista Musical Hispano-Americana, 2, febrero 1914, pp. 8-9. Salvo indicación contraria, todas las referencias hemerográficas han sido consultadas en la Hemeroteca Digital de la Biblioteca Nacional de España, http://www.bne.es/es/Catalogos/HemerotecaDigital/ (consulta 7-6-2021)

${ }^{17}$ Susan Kirkpatrick: Mujer..., pp. 60-61, 81-82, 181-194.

${ }^{18}$ Carmen Gaitán-Salinas, Idoia Murga-Castro: "Las artes decorativas, un camino hacia la modernidad: Matilde Calvo Rodero y Victorina Durán", Arte, Individuo y Sociedad, 33, 1, 2021, pp. 184-185, https://doi. org/10.5209/aris.67885 (consulta 4-1-2021).

${ }^{19}$ José Carlos Mainer: 17 de diciembre de 1927: el triunfo de la literatura, Barcelona, Taurus, 2020, pp. 201-202.

${ }^{20}$ Nerea Aresti: Médicos, donjuanes y mujeres modernas: los ideales de feminidad y masculinidad en el primer tercio del siglo XX, Bilbao, Universidad del País Vasco, pp. 69-192.

${ }^{21}$ Nerea Aresti: Masculinidades en tela de juicio, Madrid, Cátedra, 2010, pp. 121-177, 297-299.
} 
¿Existía, en realidad, algún tipo de conexión entre la creación musical contemporánea y esta confusión de roles masculinos y femeninos? Para el compositor y crítico Rogelio Villar (codirector, junto con Adolfo Salazar, de la misma Revista Musical Hispano-Americana en la que Turina había publicado su escrito anterior ${ }^{22}$ ), la cuestión tenía una respuesta afirmativa, y se evidenciaba en lo que él consideraba, en 1917, "la caricatura de lo moderno", el "modernismo" [sic] artístico y musical ${ }^{23}$ :

Vivimos en una época de afeminamiento artístico. (Así como hay hombres invertidos fisiológicamente, los hay también artísticamente). De esta especie de afeminamiento está impregnado una parte del arte contemporáneo, arte asexual. No se escribe música para hombres de sentimiento varonil; unos escriben música débil, suavemente exquisita, sin comprender que lo débil acaba por consunción, por falta de salud y de fuerza. (El sentimiento y la delicadeza del hombre sano es siempre viril, no decadente, como el del enfermo, y los artistas simplemente cerebrales, medulares, son unos enfermos); otros traspasan los límites de lo ruidoso haciendo de la música un arte de horrenda fealdad ${ }^{24}$.

Según esta visión, el afeminamiento de la música podía producirse tanto por defecto como por exceso de temperamento. Ambos extremos resultaban desequilibrados y enfermizos, además de, nuevamente, vacuos (y, por tanto, extraños a lo que pudiera considerarse una masculinidad normativa):

¡Qué cosas se oyen actualmente, señores! Desde el ramillete de confitería [...] hasta lo más aparatoso, con apariencias de grandilocuencia musical, figuraos toda clase de vaciedades sonoras. [...]

El triunfo de la sonoridad sobre la música en unos, la orquesta de gramófono (música de alfeñique, de ritmos invertebrados gelatinosos), en otros ${ }^{25}$.

Se deduce, por tanto, que un buen arte sano y viril -cuyo último gran representante musical "serio" había sido Richard Wagner, siempre segúnVillar² se encarnaría en cierta contención expresiva, respetuosa del clásico equilibrio entre forma y contenido. Incidiendo en el símil con los primores textiles que ya vimos en Turina, el mismo autor recomendaba a los creadores una máxima extraída del "Credo poético" de Miguel de Unamuno:"No te cuides en exceso del ropaje, / de escultor, no de sastre, es tu tarea" 27 .

\footnotetext{
${ }^{22}$ Sobre las diferentes posturas estéticas de ambos críticos, véase Consuelo Carredano: "Adolfo Salazar en España. Primeras incursiones en la crítica musical: la Revista Musical Hispanoamericana", Anales del Instituto de Investigaciones Estéticas, 26, 84, marzo 2004, pp. 119-144.

${ }^{23}$ Rogelio Villar: De música: cuestiones palpitantes, Madrid, Ricardo Rodríguez, 1917, p. 11.

${ }^{24}$ Ibid., pp. 9-10.

${ }^{25} \mathrm{Ibid}$, p. 7.

26 "la locomotora wagneriana, última manifestación seria del arte musical [...] pues la locomotora modernista era de bazar, para niños; pretendía ser avanzada y era casi siempre pueril". R. Villar: De música..., p. 53.

${ }^{27}$ R. Villar: De música..., p. 10.
} 
Como puede apreciarse, el neologismo "modernismo" tenía para Villar un significado peyorativo bastante similar al que le había otorgado la Real Academia al incluirlo por vez primera en su Diccionario de 1899, como "afición excesiva a las cosas modernas con menosprecio de las antiguas, especialmente en arte y literatura" ${ }^{28}$. De hecho, en el campo literario era recurrente acusar de afeminamiento o ambigüedad sexual a ciertos autores finiseculares considerados "modernistas", extranjerizantes y decadentes; una valoración que no dejaría de consolidarse durante buena parte del siglo $\mathrm{XX}^{29}$. Pese a que hacía tiempo que algunos creadores reivindicaban el término de modo desafiante ${ }^{30}$, su aplicación al terreno musical exigía, en general, algún atenuante de moderación para alcanzar una connotación positiva, como cuando el director del Conservatorio de Madrid,Tomás Bretón, alabó "la más clara sencillez y el más sano y culto modernismo" de Enrique Granados, tras su muerte en $1916^{31}$.

Ya en 1900 el jesuita y crítico vizcaíno Juan José de Lecanda había censurado, en términos no demasiado distantes de los de Villar, y aparentemente aplicables tanto a la música impresionista como al descriptivismo straussiano, que "en la música [modernista o fin de siglo] se desdeña tanto la parte melódica y se han violentado y retorcido tanto los recursos armónicos, que compositor modernista hay que pretende expresar fielmente sobre el pentagrama, con los signos musicales, el galopar de un caballo, y no de un caballo cualquiera, sino de un caballo negro precisamente" 32 . Lecanda, además, asimilaba este modernismo al de la pintura impresionista y simbolista, la arquitectura de Gaudí, el pensamiento de Nietzsche ("muerto recientemente en un manicomio"), la educación fisica escolar (introducida en España por la Institución Libre de Enseñanza) y, como no podía ser menos, las extravagancias de la moda femenina que "las revistas de moda parisienses, verdaderos agentes oficiales, imponen y reglamentan", hasta el extremo andrógino de pretender vestir a las mujeres de París y Nueva York con pantalones, "al igual que los hombres"33.

\footnotetext{
${ }^{28}$ Max Henríquez Ureña: Breve historia del modernismo, México / Buenos Aires, Fondo de Cultura Económica, 1954, p. 159.

${ }^{29}$ Susan Kirkpatrick: "Consideraciones sobre el género sexual en la configuración del hispanismo: una perspectiva estadounidense", Moenia: Revista Lucense de Lingüística \& Literatura, 4, 1998, pp. 71-78; S. Kirkpatrick: Mujer..., pp. 10, 5, 76-77.

${ }^{30}$ El predicamento positivo de la expresión en ciertos discursos minoritarios de la crítica musical española durante el período inmediatamente anterior al estreno de Las golondrinas ha sido estudiado en Teresa Cascudo: "Adesso ci vuol altra cosa: primeros usos de los neologismos modernismo y modernista en el discurso periodístico sobre música en España (ca. 1890-1910)", Revista de Musicología, 40, 2, 2017, pp. 513-42.

${ }^{31}$ Tomás Bretón: "Un recuerdo de Enrique Granados", Revista Musical Hispano-Americana, 3. ${ }^{\text {época, }}$ 4, abril 1916, p. 6.

32 Juan José de Lecanda: "La Exposición de Arte Modernista", El Nervión, 8-10-1900, citado en Javier González de Durana: Las exposiciones de arte moderno de Bilbao: 1900-1910, Donostia-San Sebastián, BassaraiArte, 2007, p. 188.

${ }^{33}$ Ibid.
} 
Al margen de valoraciones subjetivas, resulta interesante recapitular los principales rasgos que Villar, en su extenso ensayo, atribuía a la "decadente" música "modernista" -y, supuestamente, también "afeminada" - del momento: sensibilidad "enfermiza", hermetismo expresivo, sonoridades alambicadas y "exceso de detalle", complejidad rítmica, percusión excesiva, desorden de ideas, heterogeneidad de estilo, elucubraciones armónicas y desdén por la melodía. Se señala, además, un "abuso" de referencias programáticas y descriptivas, en lo que considera una fusión desconcertante con otras artes (literatura y pintura) ${ }^{34}$. Ejemplo paradigmático de este aspecto sería el género de la pantomima, que Villar valoraba solo en la medida en que la música mantuviera su autonomía frente al gesto escénico ${ }^{35}$.

Como veremos, algunas de estas características coinciden de manera significativa (aunque no necesariamente intencionada ${ }^{36}$ ) con ciertos rasgos que la crítica señalaría en el estilo de Usandizaga: en concreto, su tendencia al barroquismo de líneas instrumentales y su eclecticismo estilístico, pero también los valores plásticos y descriptivos de su música. De hecho, el número más aplaudido de Las golondrinas había sido su original y extensa pantomima del segundo acto $^{37}$. La consideración de Usandizaga como músico modernista, desde sus primeros éxitos alcanzados en el País Vasco tras su etapa de estudios parisina, ya ha sido destacada por Teresa Cascudo como un primer factor que facilitó su acercamiento al matrimonio Martínez Sierra, en un estudio que desvela innovadores (en su contexto) rasgos decadentistas en la dramaturgia musical de Las golondrinas ${ }^{38}$. El mismo trabajo apunta también la sutil incorporación de la cuestión feminista en la obra, al poner en solfa el dilema que plantea la reivindicación del "derecho a la ambición" por parte de una de las protagonistas (Cecilia, artista de circo), cuya emancipación enloquece a su amante.

En este artículo planteamos la novedosa hipótesis de que, pese al aparente entusiasmo inicial, la recepción de la obra de Usandizaga, como representante estelar de la modernidad musical de su tiempo en España, se vio mediatizada de algún modo no solo por las polémicas en torno al "modernismo", sino

${ }^{34}$ R. Villar: De música..., p. 10.

${ }^{35}$ R. Villar: De música..., pp. 15-16.

${ }^{36}$ Curiosamente, el escrito de Villar estaba dedicado a los dos críticos más eminentes del País Vasco, que habían seguido muy de cerca los primeros pasos de Usandizaga: Francisco Gascue y Juan Carlos de Gortázar (quien, bajo el seudónimo de Ignacio Zubialde había fundado la bilbaína Revista Musical de la que derivaría la propia Revista Musical Hispano-Americana).

${ }^{37}$ Tras este éxito, el matrimonio Martínez Sierra continuaría explotando este género expresivo en sucesivas propuestas escénicas, entre las que destaca, por su posterior trascendencia, la pantomima El corregidor y la molinera, con música de Manuel de Falla, estrenada el mismo año de 1917.

${ }^{38}$ Teresa Cascudo: "Del ensueño a la realidad y de vuelta al ensueño: un estudio comparativo de Saltimbanquis, Aucells de pas y Las golondrinas", De literatura y música: estudios sobre María Martínez Sierra, Teresa Cascudo, María Palacios (eds.), Logroño, Instituto de Estudios Riojanos, 2014, pp. 135-155. 
también por las connotaciones de género inherentes al mismo. Para verificarla, analizaremos, por un lado, los estereotipos sobre masculinidad y feminidad presentes en los discursos que la crítica y los medios de comunicación vertieron en torno a su creación y su figura; confrontándolos con la imagen pública del compositor según queda proyectada en documentos iconográficos y testimonios presenciales. A esta triangulación metodológica añadiremos algunas consideraciones biográficas y estéticas relacionadas con los autores de Las golondrinas y su producción, que permitirán enriquecer nuestra visión sobre la peculiar coyuntura artística y musical de España en un momento de transformaciones cruciales.

\section{Usandizaga, el vigor de un héroe musical}

Como apuntábamos al comienzo de este texto, el éxito "de coloso"39 obtenido por Usandizaga con Las golondrinas en toda España le convirtió, de la noche a la mañana, en un auténtico héroe nacional "el héroe musical más fascinante que España había conocido en muchos años"40, en expresión del crítico Christopher Webber). Más allá del logro artístico que suponía su última creación, se daba por supuesto que su pionero ejemplo marcaría el camino a otros compositores jóvenes y renovadores (como así fue, por poco tiempo), lo que permitía considerarle un auténtico jefe de filas generacional; asignándole, además, cierta misión de regeneración patriótica. Algunos, como el crítico conservador Ángel María Castell llegarían al extremo de proclamarle "el Mesías glorioso del arte lírico nacional” ${ }^{4}$.

Dicha consagración imponía una transformación de la imagen risueña de niño prodigio, casi mozartiana, con que Usandizaga se había ganado la simpatía de sus paisanos vascos en años precedentes, en favor de una caracterización más viril, madura y poderosa. Lo reconocía con claridad un editorial de la revista donostiarra Euskal-Erria: "el niño prodigio continúa siendo prodigio cada vez más sorprendente; pero de niño ha pasado a ser hombre de los que dominan en las altas cumbres del arte musical". Como puede apreciarse, el aura del compositor podía incluir trazas de aguerrido conquistador, según insinuaba Gregorio Martínez Sierra con ocasión de un pomposo homenaje tributado en el hotel Palace de Madrid (ilustración 1): “Usandizaga triunfará, venciendo siempre al público [...] El triunfo de este músico será universal y él pondrá altísimo el nombre de España"42. También el periodista Ezequiel Endériz incidía en un

\footnotetext{
${ }^{39}$ Gonzalo González: "Las golondrinas”, El Globo, 6-2-1914, p. 1.

${ }^{40}$ Christopher Webber: The Zarzuela Companion, Lanham, Maryland / Oxford, The Scarecrow Press Inc., 2002, p. 244: "The most exciting musical hero Spain had known for many years".

${ }^{41}$ Ángel María Castell: "Un gran músico: el maestro Usandizaga”, Blanco y Negro, 15-2-1914, [p. 14].

${ }^{42}$ Clave de Fa: "Las golondrinas", Euskal-Erria: Revista Vascongada, 1098, 15-2-1914, p. 112
} 
retrato moral semejante, al describirle no solo como un "genio" y un "cerebro musical", "sincero y noble", sino como "grande, joven y triunfador [...] príncipe musical" 43

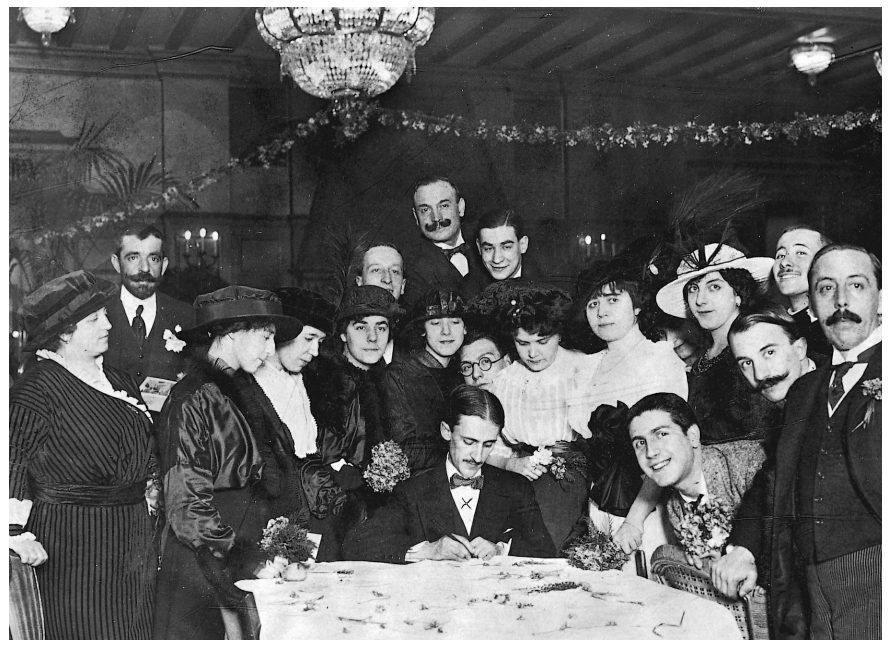

Ilustración 1. "Homenaje a un músico insigne. El maestro Usandizaga firmando tarjetas a las señoritas que asistieron ayer tarde al homenaje con que fue obsequiado en el Palace Hotel", ABC, 15-2-1914, p. 1 (Fotografía:Julio Duque)

En consonancia con esta idealización heroica, no exenta de ardor patriótico, la propia música de su exitosa zarzuela fue, en ocasiones, ensalzada con inequívocas marcas de virilidad. Quizás el más explícito al respecto fue el propio Castell, quien afirmó que, en Las golondrinas, "Usandizaga descubre un brioso temperamento dramático; su arte es varonil, severo, clásico, que matiza con destellos de pasión infinita" ${ }^{44}$. Para el crítico de El Correo Español (un diario tradicionalista y católico), estas cualidades se apreciaban desde las primeras notas de la partitura, en un preludio "de firme contextura, de solidez rítmica y de una fresca y vigorosa musa" ${ }^{45}$.Y, en opinión de Alejandro Miquis, el compositor había evidenciado "un espíritu recio y fuerte, capaz de sentir sanamente lo trágico" ${ }^{46}$. Pese a que, como veremos más adelante, otros factores y valoraciones cuestionaban esta visión idealizada, el crítico Gonzalo González resumía desde las páginas de $\mathrm{El}$ Globo la impresión favorable y generalizada en torno al hecho

\footnotetext{
${ }^{43}$ Ezequiel Endériz: "Sobre el éxito de Usandizaga", Mundo Gráfico, 121, 18-2-1914, [p. 7].

${ }^{44}$ Á[ngel] M[aría] C[astell]: "Los estrenos: Price. 'Las golondrinas", ABC, 6-2-1914, p. 8.

${ }^{45}$ V. Contreras: "Las Golondrinas: apoteosis lírica de un músico español", El Correo Español, 6-21914, p. 1 .

${ }^{46}$ Alejandro Miquis [Anselmo González Fernández]: "Los estrenos: Las golondrinas en Price”, Diario Universal, 6-2-1914.
} 
de que "un muchacho de veinticinco años haya honrado su Patria [...] con su magistral, poética y vigorosa partitura: Usandizaga, nombre que figurará al lado de los más eminentes maestros universales, gloria del arte musical español”47.

Por otro lado, Las golondrinas fue favorablemente comparada con otro tipo de producciones de moda que poblaban las carteleras españolas y eran tenidas por más decadentes y afeminadas. En concreto, Miguel Salvador aludía a la superioridad de esta obra frente a la "degeneración" en que había caído el modelo de la opereta centroeuropea tras el éxito de La viuda alegre, emulada en "una serie de operetas, de sosadas de gran espectáculo, acompañadas de la inevitable colección de valses lánguidos, fatigosísimos", con "aquellas cortes imaginarias y tanta cursilería" ${ }^{48}$. Al sentimentalismo de este tipo de obras (y, quizás, de ciertas expresiones de flamenquismo muy rechazadas en determinados círculos intelectuales) parece aludir también un crítico bilbaíno, para quien " [n]o es ciertamente la música de Las golondrinas de esa escuela al uso que delata la decadencia o anemia de los autores españoles, música de suspiros, lamentaciones o ayes dolorosos. En Usandizaga se observa genio y reciedumbre mental"49. Incluso el ultracatólico La Lectura Dominical celebraba que la obra, pese a su "sentimentalismo" convencional (y su carácter truculento, aparentemente obviado por el crítico), careciera de "la morbosa sensualidad delicuescente de los libretos de operetas al uso, y eso se va ganando" 50 .

Todas estas manifestaciones sugieren una auténtica campaña por presentar a Usandizaga con los atributos viriles propios de un paladín de las artes, necesariamente superior a sus competidores, en todos los órdenes. Se trata de un reflejo de una tendencia más amplia a convertir al autor (siempre masculino) del último éxito del momento en un ídolo musical incontestable, en consonancia con el paradigma de artista-héroe romántico -el titánico "hombre-de-verdad" beethoveniano, según señaló hace tiempo la crítica feminista ${ }^{51}$ - que se venía fraguando desde el siglo anterior. Posiblemente, esta estrategia resultaba conveniente para el negocio teatral, pero podía ser cruel con los propios creadores, sometidos a una feroz lucha por la supremacía. Así lo observaría Manuel Fernández Núñez al cabo de solo un año:

Primero fue Luna el mejor compositor, y aquellos Molinos [de viento] era la última palabra en su género. A su idolatría substituyó la de Usandizaga, y después la de Vives, y luego la de Turina y más tarde la de Falla. Con este sistema puede

\footnotetext{
${ }^{47}$ G. González: "Las golondrinas...".

${ }^{48}$ Miguel Salvador: "El drama lírico 'Las golondrinas", Revista Musical Hispano-Americana, 2-2-1914, p. 4.

${ }^{49}$ T. M.: "En los Campos Elíseos: 'Las golondrinas", El Liberal, Bilbao, 13-6-1914.

${ }^{50}$ P. Caballero: “Crónica teatral”, La Lectura Dominical, 14-2-2020, p. 106.

51 Teresa Cascudo: "Los trabajos de Penélope musicóloga: musicología y feminismo entre 1974 y 1994", Música y mujeres: género y poder, Marisa Manchado (ed.), Madrid, Horas y horas, 1998, p. 180.
} 
profetizarse el resultado sin temor a equivocaciones... Todos los que ídolos un día, vuelvan a estrenar, será para lanzarlos por la borda, sin consideraciones al papel que anteriormente se les adjudicó ${ }^{52}$.

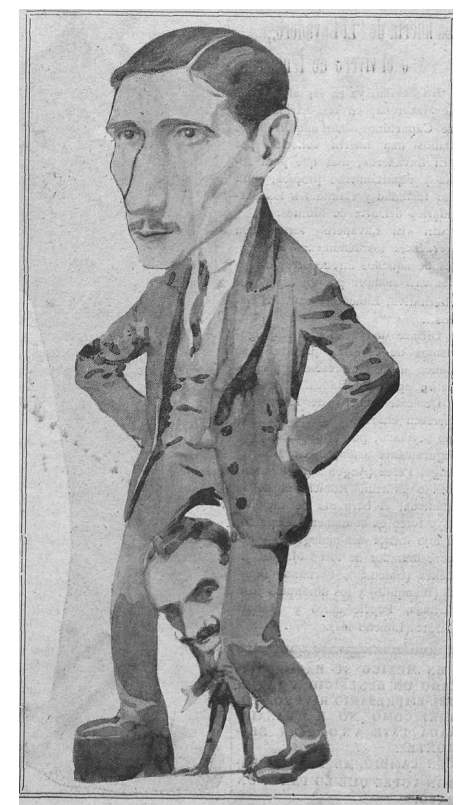

Ilustración 2. "El maestro Usandizaga: el grande hombre de 'Las golondrinas",, The kon leche: krónica taurómaka, 9-2-1914, p. 6

En el caso de Usandizaga, esta campaña mediática de consagración tuvo una rápida repercusión también institucional. En efecto, en abril de 1914 fue nombrado académico correspondiente de la Real Academia de Bellas Artes de San Fernando a propuesta de los eminentes compositores Tomás Bretón, Emilio Serrano y Joaquín Larregla ${ }^{53}$; honor insólito para un joven de apenas veintisiete años y $\tan$ corta carrera.

\section{Genio y figura: la imagen publicada}

En contraste con los palpables esfuerzos de la crítica por hacer encajar a Usandizaga en un tradicional modelo de virilidad heroica, muchas crónicas contemporáneas coincidían también en señalar el dramático abismo

52 Manuel F[ernández] Núñez: "La ópera española", Arte Musical, 1, 24, 31-12-1915, p. 2.

${ }^{53}$ Mario Lerena: "Usandizaga Soraluce, José María", Auñamendi Eusko Entziklopedia, Eusko Ikaskuntza, 2021, http://aunamendi.eusko-ikaskuntza.eus/es/usandizaga-soraluce-jose-maria/ar-134577/ (consulta 4-1-2021). 
existente entre "el músico triunfador en medio de tanta gloria resplandeciente" y la "figurita menuda y desarticulada" 54 de aquel "muchacho desmedradillo, de modesto porte" 55 . "La música que hace este chico prodigio no responde a su estructura fisica ni a su apacible carácter", advertía el mismo crítico bilbaíno que ensalzaba la "reciedumbre" de su inspiración ${ }^{56}$. En efecto, el músico arrastraba desde su infancia una notoria cojera, además de los padecimientos, cada vez más evidentes, de la devastadora tuberculosis que acabaría con su vida al año siguiente. Quizá nadie acertara a reflejar esta realidad con tan misericorde patetismo como la aún adolescente Matilde Muñoz:

Usandizaga, a quien hubiéramos imaginado un hombre lleno de vida, fuerte para la lucha cruenta de gloria e ideal a que se había lanzado, se presentaba más empequeñecido y más infantil ante la multitud, que le reclamaba en oleada ardiente, y saludaba con un gesto modesto y breve, vacilando sobre las piernas endebles y dobladizas, que arrastraba con un disimulado esfuerzo, haciendo oscilar la cabeza, muy voluminosa, donde brillaban, aplastado y peinados con un meticuloso dandinismo [sic] los oscuros cabellos.

Nadie hubiera imaginado que Usandizaga, que hasta por la fuerza fonética del apellido se nos figurara vigoroso y un poco agreste, como hijo de la áspera y ruda Vasconia, fuera aquel muchachito enclenque $[\ldots]^{57}$.

Por su parte, María Lejárraga recordaba los desvelos del músico por no defraudar las expectativas de varonía que en los círculos de sociabilidad nocturna madrileña se le suponían a un personaje público de su relieve:

Por la edad era hombre; por el extraordinario éxito, el héroe del día; por la voluntad, chiquillo mimado y testarudo [...] Si, dejándose arrastrar por las invitaciones de sus admiradores, había bebido una copita de lo fuerte, no porque le atrajese la bebida, sino para demostrar que era tan hombre como el que más, al llegar a casa se ponía el termómetro alarmadísimo, por ver si le había subido la fiebre, su perdurable compañera ${ }^{58}$.

Para sus admiradores, esta consunción física no hacía más que engrandecer la fortaleza de espíritu del compositor. Aun así, no faltaron quienes se recrearon en inevitables caricaturas gráficas, con grados de simpatía o crueldad variables. Por ejemplo, junto a un titular que ensalzaba a Usandizaga como "el grande hombre de Las golondrinas", la revista

${ }^{54}$ Matilde Muñoz: "Usandizaga", De música: ensayos de literatura y crítica, Madrid, El Imparcial, 1917, p. 49.

${ }^{55}$ A. M. Castell: "Los estrenos...".

56 T. M.: "En los campos Elíseos...".

${ }^{57}$ M. Muñoz: "Usandizaga", pp. 4-5.

${ }^{58}$ María Martínez Sierra: Gregorio y yo: medio siglo de colaboración, México, Gandesa, 1953, pp. 114-115. 
humorística The kon leche publicó una imagen agigantada del compositor que evidenciaba sus necesidades ortopédicas, con un diminuto Gregorio Martínez Sierra jugueteando entre sus piernas (ilustración 2). La complexión marcadamente débil del músico y también de su libretista -cuya masculinidad, al menos en el plano autoral, era recurrentemente puesta en entredicho ${ }^{59}$ - fue también satirizada, de forma denigrante, en el número de carnaval del semanario El Duende, con dos caricaturas gemelas que mostraban las infantiloides figuras de ambos creadores paseados de la mano por, respectivamente, Emilio Sagi Barba (ilustración 3.a) y la actriz Catalina Bárcena, amante de Gregorio, quien aparece ridículamente ataviado de Juan Tenorio (ilustración 3.b).

a)

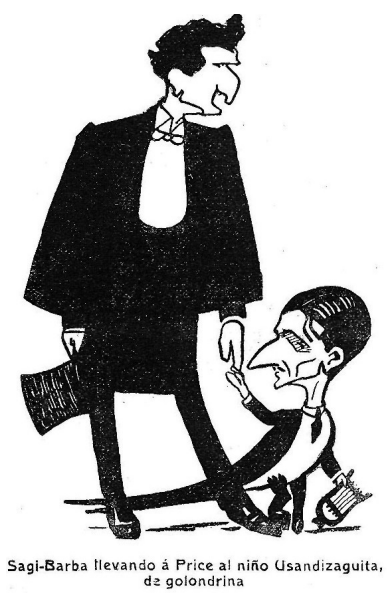

b)

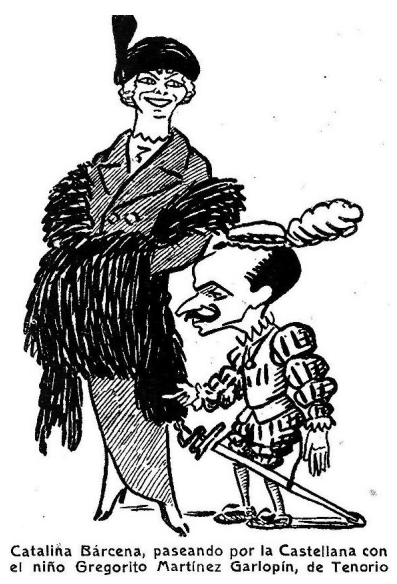

Ilustración 3. Caricaturas de Emilio Sagi Barba y Usandizaga, Catalina Bárcena y Gregorio Martínez Sierra. "Del homenaje a los autores de Las golondrinas", El Duende, 22-2-1914, pp. 6-7

Respecto al "dandismo" apuntado por Muñoz, las imágenes conservadas muestran al compositor vestido con pulcritud y discreta elegancia: traje oscuro y chaleco, camisa blanca de gruesísimos cuellos almidonados, fina corbata (más que pajarita), ocasionales sombreros canotier y gorras o boinas; inevitable bastón, pequeño bigote, y un pelo muy corto, peinado y

59 "No hay derecho a hacer chistes de nuestra lamentable virilidad", protestaba el propio Gregorio en el primer número de su revista Renacimiento (1907), citado en J. Montero Padilla: "Gregorio...", p. 19. "Gregorio era, en el sentido noble y espiritual de la palabra, absolutamente femenino, quizás más que ella [su mujer María]", afirmaría César González Ruano: "No nos gusta María", Arriba, 14-11-1952, p. 8, citado en Julio Enrique Checa Puerta: "La mariposa de presa: algunas claves del Teatro de Arte", El Teatro de Arte. Libro de las Jornadas de zarzuela 2015, Alberto González Lapuente, Alberto Honrado Pinilla (eds.), Madrid, Fundación Jacinto e Inocencio Guerrero, 2016, p. 41. 
engominado (en contraste con la tradicional melena alborotada de los artistas bohemios) ${ }^{60}$. Como curiosidad, cabe señalar que otro semanario satírico, El Mentidero, aprovechó una muy difundida fotografia del compositor para introducir el irónico reclamo de una marca real de cosmética capilar: "El maestro Usandizaga triunfó: primero, por su música; después, al presentarse en el escenario, por su cabellera abundante y lustrosa, que da a su rostro aspecto genial.Y es que el gran músico vasco, a pesar de lo mucho que trabaja, no olvida un solo día friccionarse la cabeza con el soberbio Regenerador Paz del Cabello [...]"61.

Burlas aparte, la contradicción entre el forzado arquetipo masculino supuesto a un creador genial como Usandizaga y la evidente fragilidad de su cuerpo aniñado y enfermo quedó de manifiesto apenas un año después de su muerte, cuando los reyes de España inauguraron solemnemente el monumento que las autoridades donostiarras erigieron en honor de su ilustre paisano. Se trataba de un elegante conjunto realizado por el afamado escultor Josep Llimona, quien, pese a haber militado en las filas del modernisme finisecular planteó aquí unas líneas sobrias y bastante clásicas, de cierto aire novecentista: tan solo unas suaves volutas en los extremos del banco basal recuerdan con discreción al ya viejo art nouveau. El busto de Usandizaga, de marcados rasgos apolíneos y anchos hombros, casi atléticos, se alza sobre una robusta columna jónica, a cuyos pies, en posición de evidente subordinación, una muchacha (¿musa?) muestra su serena aflicción (ilustración 4). Pese a la armonía de este trazado, una parte del público congregado protestó porque el retrato de su ídolo no se ajustaba a la verdadera imagen del personaje que habían conocido en persona. Llimona se vio entonces en la necesidad de publicar un alegato en el conservador El Pueblo Vasco, defendiendo la conveniencia de idealizar "la figura enfermiza y débil del gran músico" para ajustarse a un canon de clásica ortodoxia: "un busto de esta concepción [realista] rompería la estética del conjunto y seguramente con el tiempo habría de ser sustituido. Todo el conjunto responde a una idea de sencillez y solidez, evitando toda clase de adornos" $"$.

\footnotetext{
${ }^{60}$ Puede consultarse un amplio repositorio de imágenes públicas y privadas del compositor en https:// www.eresbil.eus/web/usandizaga/ (consulta 4-1-2021).

61 "El triunfo de Usandizaga", El Mentidero, 56, 14-2-1914, p. 10.

${ }^{62}$ José Llimona: "Al culto pueblo de San Sebastián", El Pueblo Vasco, 26-9-1916, p. 1, citado en Jesús M. ${ }^{a}$ de Arozamena: Joshemari..., p. 312.
} 


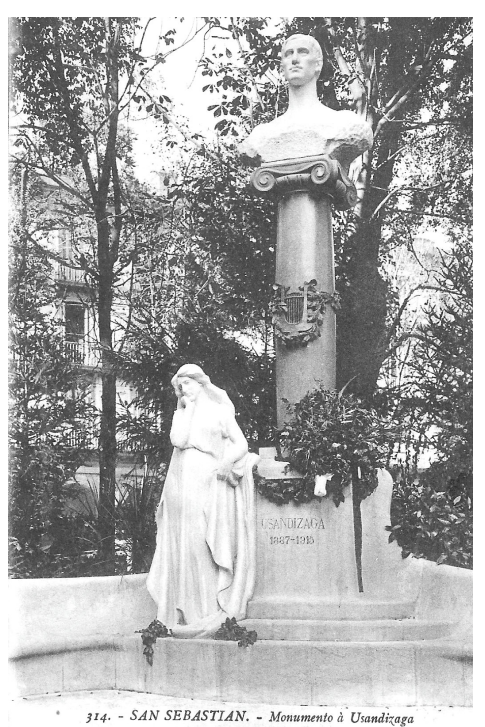

Ilustración 4. Tarjeta postal del monumento a Usandizaga en San Sebastián, de Josep Llimona.

Tarjeta Postal Universal, San Sebastián, s.f. (Fotografía: Gregorio G[onzález] Galarza)

\section{Contra el Modernismo: ornamento, moda y otros pecados}

Como puede entreverse en las palabras y en la propia obra de Llimona, los atributos de fuerza, sobriedad y equilibrio invocados para la representación "moral" del músico coinciden con los términos empleados por Castell para definir el estilo musical de Las golondrinas ("varonil, severo, clásico"63), y son propios de una masculinidad templada, muy reivindicada en las primeras décadas del siglo XX en oposición a los excesos concupiscentes del don Juan y del hombre afeminado ${ }^{64}$. Tal y como vamos a descubrir en este apartado, estos ideales no solo entraban en conflicto con la condición fisica de Usandizaga, sino también con algunos desequilibrios que buena parte de la crítica detectó y no dejó de censurar en su obra.

Quizá un primer indicio de esta desviación heterodoxa lo podamos encontrar en la propia naturaleza desbordante e irracional de la "apoteosis lírica" 65 de Usandizaga en Madrid. Si bien este tipo de reacciones exaltadas son hasta cierto punto comunes cuando hablamos de arte musical y, en especial, teatro lírico, los medios recalcaron con inusitada vehemencia lo extremado de este fenómeno: un éxito "delirante, frenético, brutal [...] absolutamente loco" ${ }^{66}$, en palabras

\footnotetext{
${ }^{63}$ A. M. Castell: "Los estrenos...".

${ }^{64}$ N. Aresti: Médicos..., pp. 137-143; N. Aresti: Masculinidades..., pp. 25, 122-12, 265-66.

${ }^{65}$ V. Contreras: "Las Golondrinas...".

${ }^{66}$ A. M. Castell: "Los estrenos...".
} 
de Castell. Según el cronista de El Globo, "[t]odo el público, en pie, aplaudía con entusiasmo: las señoras, con delirio; los entendidos en música, con emoción; con religiosidad, los profanos. [...] Toda la partitura fue aplaudida con verdadero frenesi" $"$ " “No " "No nos hemos salido todos algo de quicio en este asunto?", se preguntaba, al cabo de unas semanas, el futuro presidente de la Sociedad Nacional de Música, Miguel Salvador, reconociendo que "sobre todo esto pesa algo... jno sé qué!... de excesivo y ruidoso, como toda exageración"

De hecho, frente al entusiasmo generalizado, algunas voces mostraron ciertos reparos ante la extravagancia y el ecléctico exotismo de la partitura-comparada por Alejandro Miquis con "un jardín de plantas exóticas" pudding, el conglomerado de retazos desafines", de efecto "rapsódico" "70, por Salvador-. En este sentido, la cuestión del "modernismo" surgió inevitablemente entrelazada con una reivindicación nacionalista de la tradición autóctona y popular ${ }^{71}$. Así, los defensores de Las golondrinas se preocuparon de ponderar el carácter mesurado de las innovaciones de Usandizaga en una obra que el wagneriano Joaquín Fesser ${ }^{72}$ definió como "modernísima pero no modernista" "3; no faltando quien destacase que "a pesar de la enseñanza de d'Indy y de la 'Schola Cantorum', en la música de Usandizaga no se huye ni se niega el carácter español" e, incluso, "de Vasconia" 74 . Todo lo contrario opinaba el acérrimo crítico de El Duende, que aprovechó para poner veladamente en duda la virilidad del autor, con el habitual tono insidioso de dicha revista: "Nos causa en verdad mucha tristeza, ver a un músico como Usandizaga aferrado a las teorías modernistas de la perniciosa escuela francesa, muy empeñada en

\footnotetext{
${ }^{67}$ G. González: "Las golondrinas..."

${ }^{68}$ M. Salvador: "El drama lírico...", p. 3. Es interesante subrayar el carácter moderadamente renovador y enemigo de estridencias que, como buen representante de la élite social e intelectual del momento, caracterizó al autor de la crítica. Teresa Cascudo: "Humor y pedagogía en las críticas de Miguel Salvador, el crítico buen aficionado de El Globo (1904-1913)", Los señores de la crítica: periodismo musical e ideología del modernismo en Madrid (1900-1950), Teresa Cascudo, María Palacios (eds.), Sevilla, Doble J, 2012, pp. 1-54. Agradezco al musicólogo Miguel Ángel Ríos Muñoz esta referencia.

${ }^{69}$ A. Miquis: "Los estrenos...".

${ }^{70}$ M. Salvador: "El drama lírico...", p. 5.

${ }^{71}$ La recurrente confrontación dialéctica entre modernismo y nacionalismo ha sido señalada en T. Cascudo: "Adesso...", pp. 519-521.

${ }^{72}$ Emilio Casares Rodicio: "Fesser, Joaquín", Diccionario de la música española e hispanoamericana, Emilio Casares Rodicio (dir.), Madrid, SGAE, 1998, vol. 5, p. 105.

${ }^{73}$ Tristán [Santiago Peña y Goñi]: "Teatro de Price: 'Las golondrinas", El Liberal, Madrid, 6-2-1914, p. 3. Basamos la atribución de autoría de esta crítica en Emilio Casares Rodicio: "Crítica musical desde la segunda mitad del siglo XIX al siglo XX. Construcción historiográfica, debate estético, recepción y búsqueda del idioma propio a través de la crítica madrileña y barcelonesa", Música lírica y prensa en España (18681936): ópera, drama lírico y zarzuela, José Ignacio Suárez García, Ramón Sobrino, María Encina Cortizo (eds.), Oviedo, Servicio de Publicaciones de la Universidad de Oviedo, 2018, p. 60.

${ }_{74}$ [Alejandro] S[aint]-A[ubin]: "Vida teatral: Price - 'Las golondrinas", El Heraldo de Madrid, 6-21914, p. 2. Basamos esta atribución de autoría en Emilio Casares Rodicio: "Crítica musical...", p. 64.
} 
interpretar y describir el ruido de una silla que se arrastra, de una puerta que se cierra o de un carro que pasa, pero impotente para expresar el alma de un pueblo" 75 .

Sin llegar a tal extremo, también desde el País Vasco el Padre José Antonio de Donostia lamentó la ausencia de raíces vernáculas en Las golondrinas; un abandono que atribuía a la influencia del entorno familiar (alto-burgués) del músico. En efecto, en una carta dirigida al patriarca del nacionalismo musical hispano Felipe Pedrell, el fraile capuchino tachaba el último estreno de Usandizaga de ridículo y "cursi" "76: curiosamente, el mismo calificativo que, como vimos, Miguel Salvador reservaba a la opereta extranjerizante.

No obstante, es otro aspecto del estilo de Usandizaga el que centraba los mayores reparos de la crítica y, al mismo tiempo, el que con más claridad podía desafiar una concepción normativa de la masculinidad. Se trata de su escritura abigarrada y un tanto confusa, fruto de una profusión de líneas contrapuntísticas que algunos atribuyeron a una "luna de miel" del autor con "la técnica"77 pero que, de forma más genérica, se entendió como tendencia a una ornamentación superabundante y hasta enfermiza -un "barroquismo de adorno e instrumentación" 78 , en expresión del mismo Salvador-. Se extendería en esta cuestión el sacerdote y organista guipuzcoano Juan Bautista Elustiza en una conferencia leída en Sevilla a finales de 1915 y reproducida tres años más tarde por un directo discípulo de Pedrell, el también religioso Luis Villalba:

Usandizaga es en su instrumentación algo recargado, pinturero y barroco. Hace alarde desmedido de su dominio en el manejo de los instrumentos, de su conocimiento de los secretos y resortes de la orquesta, de las múltiples sonoridades que adquieren unos instrumentos al hermanarse con otros [...] En toda su obra se nota este barroquismo insano, mezcolanza admirable de lo clásico y moderno [...] algo impreciso y vago $[\ldots]^{79}$.

Como se recordará, esta confusión de sonoridades y líneas instrumentales era una de las características que Rogelio Villar identificaba en lo que él consideraba "modernismo" afeminado. El propio Elustiza relacionaba esta tendencia de Usandizaga a "escribir intrincadas partituras atiborradas de ciencia musical" con la de músicos "snobs", "a la moderna" ${ }^{80}$. Más aún, su descripción se asemeja a la de las pedantes filigranas sonoras que Turina atribuía a las alumnas de la Schola Cantorum de París. Quizá en prevención

\footnotetext{
75 "Del homenaje a los autores de 'Las golondrinas", El Duende, 22-2-1914, p. 7.

${ }^{76}$ Carta de José Antonio de Donostia a Felipe Pedrell, 20-11-1915, citado en José Luis Ansorena: "La alternativa de José M. ${ }^{a}$ Usandizaga”, Las golondrinas, Madrid, Teatro Real, 1999, p. 83.

${ }^{77}$ A. Miquis: "Los estrenos...".

${ }^{78}$ M. Salvador: "El drama lírico...", p. 6.

${ }^{79}$ Juan B[autista] Elústiza: "Prólogo a una audición a las obras de Usandizaga", conferencia citada en Luis Villalba Muñoz: José María Usandizaga, Madrid, Viuda de Pueyo, 1918, p. 18.

${ }^{80}$ J. B. Elústiza: "Prólogo...", citado en L. Villalba: José María..., p. 16.
} 
de semejantes ataques, un admirador de Las golondrinas se afanaba en subrayar que la "riqueza" de sus "recursos exuberantes" y "modernas técnicas orquestales" no incurría en "el barroquismo decorativo que impera en las óperas contemporáneas" 81 .

En realidad, dicha tendencia no haría sino acentuarse en la siguiente composición escénica de Usandizaga, su ópera póstuma La llama; una fastuosa fantasía oriental con libreto de Martínez Sierra estrenada a comienzos de 1918 en San Sebastián y Madrid. Para Villalba, la obra -"de armonías rebuscadas en el fondo de laberintos dificilísimos", según la prensa donostiarra ${ }^{82}$ - se asemejaba a un "mosaico donde parece haberse pretendido reunir lo más efectista y deslumbrador de cada campo artístico" 83 , con "toda la vaguedora [sic] sonoridad del sensualismo modernista" ${ }^{\prime 4}$.

Sería la corrosiva pluma de Adolfo Salazar la que, a propósito del estreno madrileño de La llama, relacionase de un modo más directo el "modernismo" de Usandizaga, que él encontraba ya caduco ("todo muy moderno, salvo el concepto", le achacaba), su profusión orquestal y escénica, y los banales perifollos de la moda femenina ${ }^{85}$. En su crónica, Salazar se burlaba del "aderezo modernista" que adornaba la partitura y la escenografía de la ópera con "las fórmulas de moda" y que, en el caso de la música, le parecían "triviales imitaciones del penúltimo figurín francés", entremezcladas con trazos veristas y ecos de los ballets russes de Diaghilev. Abundando en el ya tópico (y misógino) paralelismo con el mundo de la costura, llegaba a juzgar los efectos orquestales de Usandizaga como meros "abalorios", comparables a cualquier "aditamento", entre "fashionable" y "hortera", de "la moda sastreril" $"$.

Para Salazar, estos defectos aparecían ligados a otras dos cuestiones: por un lado, el impropio uso del folklore nacional, desprovisto de verdadero color local (de nuevo, según un patrón nacionalista); por otro, un exceso de complacencia con los gustos del gran público, al que se pretende halagar y deslumbrar a toda costa (una masa de admiradores, añadimos, que incluía a mujeres diletantes, y no solo al elitista círculo de intelectuales varones al que pertenecía Salazar ${ }^{87}$ ).

\footnotetext{
${ }^{81}$ Castejón: "Apuntes musicales: estreno de Las golondrinas", Heraldo de Aragón, 26-4-1914.

82 "El rotundo triunfo de 'La llama", El Noticiero, 31-1-1918.

${ }^{83}$ L. Villalba: José María..., p. 24.

${ }^{84}$ Ibid., p. 29.

${ }^{85}$ Adolfo Salazar: "Gran Teatro: La llama, ópera en tres actos de José M. ${ }^{a}$ Usandizaga y Gregorio Martínez Sierra”, España, 4-4-1918, p. 12.

${ }^{86}$ A. Salazar: "Gran Teatro..."

${ }^{87}$ Sobre el elitismo estético de dichos círculos, véase Francisco Parralejo Masa: El músico como intelectual: Adolfo Salazar y la creación del discurso de la vanguardia musical española (1914-1936), Madrid, SEdeM, 2019, pp. 50-76; sobre el posible homoerotismo misógino latente en la sociabilidad de Salazar, véase María Palacios: La renovación musical en Madrid durante la dictadura de Primo de Rivera: el Grupo de los Ocho (1923-1931), Madrid, SEdeM, 2008, pp. 210-214.
} 
Con un tono más sosegado, reconocía que Las golondrinas podía ser considerada una obra "de lucha", mientras que La llama era un fallido proyecto "de conquista" $"$. Desarrollando el lenguaje figurado del crítico, podríamos deducir que el belicoso héroe de la patria habría sucumbido a dos debilidades tenidas por típicamente femeninas: coquetería y vanidad. O, si se quiere, había renunciado a la primera línea de la vanguardia musical española en favor de una posición más acomodaticia.

Paradójicamente, los elogios ditirámbicos que buena parte de la prensa más biempensante continuaba dedicando también al estreno de $\mathrm{La}$ llama no hacían sino alimentar las sospechas de que, al contrario de lo ocurrido en 1914 con Las golondrinas, su modernismo carecía ya de verdadero valor revulsivo para la élite artística e intelectual de la España de 1918. No por casualidad Manuel de Falla y el propio Salazar venían defendiendo desde 1915 un paradigma de "música nueva" aparentemente ajeno a la noción de "modernismo" corriente en España hasta el momento. De hecho, Falla daba la razón a quienes acusasen de "decadentismo" a una música continuadora de los ideales del "arte tradicional" "con la única diferencia del uso de ciertos procedimientos que [...] bien pudieran atribuirse a lo que el vulgo llama moda". Además, abjuraba expresamente de cualquier "eclecticismo" estético, desdeñando al ecléctico como un sujeto carente de ideas, o bien "un tímido o un perezoso con apariencias de amable urbanidad condescendiente [...] un ser esterilizado (perdón por la palabrilla)" $" 89$.

Un lustro más tarde, el crítico Juan de la Encina -uno de los ideólogos del arte vasco contemporáneo- confirmaría la tibieza renovadora que caracterizaba el ecléctico y mercantil "snobismo modernista" de "los empresarios y los artistas del Eslava" (es decir, de la compañía de Martínez Sierra), cuestionando, al mismo tiempo, la vigencia del concepto y el propio término de "modernismo" ${ }^{90}$. Una vez más, se recalcaba la cercanía de dicho movimiento al mundo femenino de la moda, si bien con unas connotaciones de gracia y finura más benevolentes que en ejemplos anteriores:

¡Modernistas! ¡Modernistas!... He aquí algo que no entendemos bien. Modernismo ¿de cuándo?, ¿de qué época? Porque, para nuestra confusión cosmopolita tan modernista es, verbigracia, un cuadro de Renoir, ya muerto y declarado discretamente clásico del arte francés, como Picasso [...]. Si con el vocablo modernismo

${ }^{88}$ A. Salazar: "Gran teatro...".

${ }^{89}$ Manuel de Falla: "Introducción al estudio de la Música nueva", Revista Musical Hispanoamericana, diciembre 1916, p. 3 (fragmentos de una conferencia leída en el Ateneo de Madrid en 1915).

90 Juan de la Encina (Ricardo Gutiérrez Abascal): "El té chino", La Voz, 23-2-1921, citado en Juan de la Encina y el arte de su tiempo (1883-1963), Museo de Bellas Artes de Bilbao / Museo Reina Sofía, 1998, p. 124. 
queremos significar la moda, ¿por qué hemos de rechazar a los difundidores de ella?, ¿por qué, pues, no hemos de seguir la moda de los artistas? ¿Hemos de ser menos discretos y renovadores que las mujeres??11.

\section{La “seducción” decadentista: dramaturgia y vida}

Ciertamente, no era difícil atribuir a la influencia de los Martínez Sierra la deriva del último Usandizaga hacia este modernismo un tanto comercial, que introducía gestos de audacia en expresiones y formas de fondo convencional, no demasiado lejanas a las de la zarzuela y la opereta contemporáneas. El propio Gregorio reivindicaría el refinamiento en escenografia, vestuario y aun maquillaje de su compañía teatral como "escaparate y espejo de la moda" para halagar la vista de "los elegantes" de una voz acusara a Martínez Sierra de haber corrompido la supuesta integridad artística de Usandizaga, insinuando incluso una relación de atracción pecaminosa. En palabras de Joaquín Fesser, “el alma de Usandizaga era cándida y dócil. El talento de Martínez Sierra fue para ella un seductor. Usandizaga, en manos de su nuevo 'libretista' y consejero, fue glorificado por las masas impresionables... y perdido para el arte" ${ }^{93}$. Según resumiría el agustino Luis Villalba poco después, "se ha hecho figurar a Martínez Sierra como el ángel seductor que ha sacado del paraíso regional al ingenuo compositor que vagaba inocente entre sus euskaras montañas para introducirle en la Babel mundial del arte" ${ }^{94}$.

Leídas al pie de la letra, estas expresiones figuradas remiten a un homoerotismo sorprendentemente explícito. Sin embargo, es probable que la conocida autoría femenina oculta bajo la firma de Martínez Sierra estuviese en la mente de casi todos los que así se expresaban. Desde esa perspectiva, la imagen del “ángel seductor" incidiría en una visión de María Lejárraga de Martínez Sierra como mujer fatal y corruptora de hombres. En cualquier caso, semejantes argumentos implicaban un menoscabo de la autonomía y potencia creadoras de Usandizaga, al suponerle un carácter poco maduro, voluble y fácilmente manipulable; en suma, aniñado o falto de hombría. Es curioso que, en sentido inverso, María Martínez Sierra atribuyera a la música de Usandizaga una "sensualidad asiática" ajena a su hipotética influencia, y "exacerbada por las fiebres lentas pero constantes de la tuberculosis" $"$. Para la libretista, esta vena provendría

\footnotetext{
${ }^{91}$ J. de la Encina: "El té...", p. 123.

92 Programa de mano de El reino de Dios, Teatro Eslava, 22-11-1916, citado en Julio Enrique Checa Puerta: "La actividad empresarial de Gregorio Martínez Sierra: una apuesta renovadora en la órbita del teatro comercial de preguerra", Anales de la Literatura Española Contemporánea, 23, 3, 1998, p. 844.

${ }^{93}$ Joaquín Fesser: "Revista de música: Gran Teatro. 'La llama”, El Sol, 2-4-1918, p. 6.

${ }^{94}$ L. Villalba: José María..., p. 27.

${ }^{95}$ M. Martínez Sierra: Gregorio..., p. 107.
} 
del "hechizo" producido en él por las primeras exhibiciones de ópera rusa organizadas por Diaghilev en París; una música que su maestro, el ultracatólico Vincent D'Indy había tildado de "pecado mortal"". A esta influencia cabría añadir la de alguna incursión del joven Usandizaga entre la bohemia nocturna parisina con el fin de admirar a estrellas de cabaret como la Bella Otero ${ }^{97}$.

En realidad, era el músico quien, por propia iniciativa, había escogido el drama Saltimbanquis de los Martínez Sierra como base argumental de Las golondrinas ${ }^{98}$. En cuanto a su colaboración en La llama, María Martínez Sierra dejó claro que todo su trabajo se había plegado a las febriles ansias expresivas del compositor. De hecho, la correspondencia epistolar del músico sugiere que fue él quien propuso los detalles más escabrosos de la trama. Así ocurrió con el elemento más perturbador en lo que respecta a estereotipos de género: la odalisca asesina Aisa, claro eco de la "salomanía" decadentista de aquellos años, a quien Usandizaga quería ver enfrentada en duelo con su rival masculino, en contra de los reparos morales de Gregorio (o María):

Como observará usted, hemos procurado tener en cuenta sus disposiciones. Dos de ellas son imposibles: el duelo, porque no tiene realidad humana que una mujer desafie a un hombre... Una mujer mata como puede, a traición, porque es más débil. Podría costarnos un disgusto con el público. Tampoco me parece oportuno que la quemen viva, y tres muertes me parecen demasiadas muertes ${ }^{99}$.

En definitiva, al margen de la influencia que los Martínez Sierra pudieran ejercer, la sensibilidad de Usandizaga aparece saturada de modernismo decadentista, con su tendencia a situaciones morbosas, disolventes o transgresoras de género: no en vano tenía a Oscar Wilde como autor de cabecera en su lecho de muerte, según atestiguó el también literato modernista Tomás Borrás ${ }^{100}$. De hecho, el modernismo musical de Usandizaga aparecía ya bien definido en su producción anterior a Las golondrinas en títulos como su "fantasía-danza" Hassahn et Melihah (1912), cuyo programa nos traslada a un espectáculo de titiriteros en una feria oriental ${ }^{101}$. La vena más decadentista de aquel modernismo la

\footnotetext{
96 "Y sucedió lo que suele ocurrir con las novelas pornográficas que algunos autores escriben -según dicen ellos- para mostrar la abominación del pecado". M. Martínez Sierra: Gregorio..., pp. 106-7.

${ }^{97}$ Jesús M. ${ }^{a}$ de Arozamena: Jesús Guridi: inventario de su vida y de su música, Madrid, Editora Nacional, 1967, p. 56; J. M. Arozamena: Johemari... pp. 88-89.

${ }^{98}$ M. Martínez Sierra: Gregorio..., p. 104; J. M. Arozamena: Joshemari..., p. 227.

${ }^{99}$ Carta de Gregorio Martínez Sierra a Usandizaga, s. f. [1915], citada en J. M. Arozamena: Joshemari..., p. 281.

100 Tomás Borrás: "El pobre Joshe Mari”, La Tribuna, 5-2-1918, citado en J. M. Arozamena: Joshemari..., p. 281. El cronista madrileño hace referencia a un inexistente, o no localizado, volumen de Opiniones de Wilde; probablemente en referencia a su colección de ensayos estéticos Intentions (1891).

${ }^{101}$ José M. ${ }^{a}$ Usandizaga: Hassan y Melihah [partitura manuscrita], Rentería (Guipúzcoa), Archivo Vasco de la Música ERESBIL, Fondo 050/064.
} 
encontramos en su inédita comedia lírica Bitz, cuya partitura, sobre un libreto en el que debió de intervenir su tío Cándido Soraluce, sería completada por un desconocido compositor estadounidense, W. K. Hamilton ${ }^{102}$. Con un tono desenfadado de opereta y un formato propio del denostado "género ínfimo", la obra recrea la excéntrica y disipada vida estival de Biarritz inmediatamente antes del estallido de la guerra, presentando a sus dos protagonistas - una sensual canzonetista y una cocotte "yanqui"- como "marilocas enzarzadas en disputarse el tipo más estrafalario" "103; una descripción que, en sentido figurado y cáustico, encajaría bien dentro del misógino discurso contra el arte y los artistas modernistas que hemos venido rastreando.

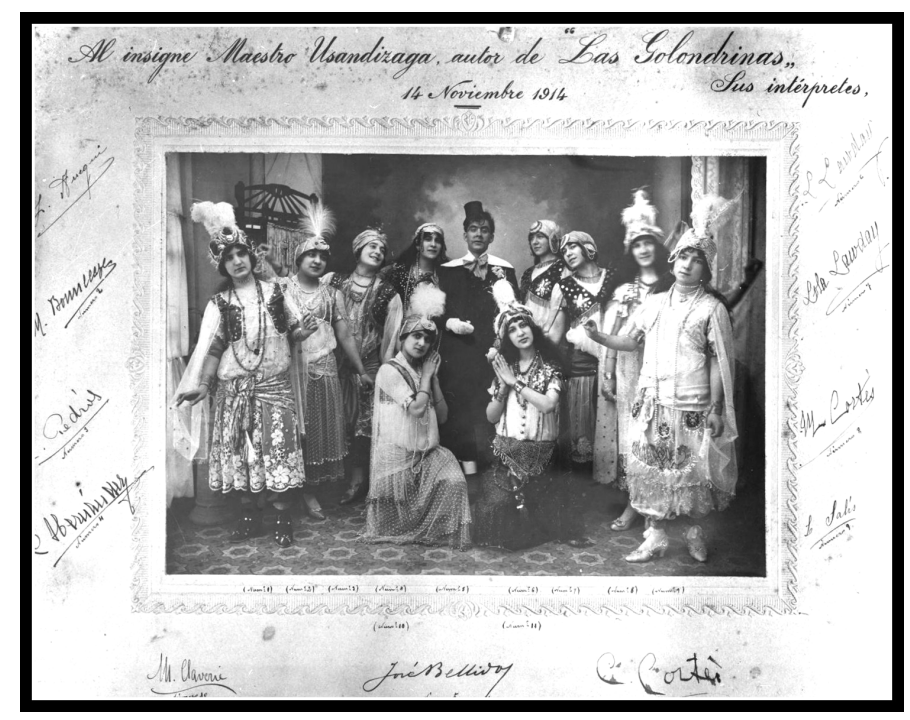

Ilustración 5. Fotografía del coro de "bailarinas moras" de Las golondrinas en su estreno barcelonés, dedicada por sus intérpretes al autor el 14-11-1914 (Rentería, Guipúzcoa, Archivo Vasco de la Música ERESBIL ${ }^{104}$ )

De hecho, el erotismo operetesco y casi "sicalíptico" de Bitz asomaba también en Las golondrinas, si bien la crítica eludió o trató de forma muy tangencial dicho elemento. En efecto, el segundo acto de la obra nos introduce en un circo de variedades donde un coro de sugerentes "bailarinas

102 Mario Lerena: "No me olvides': fuentes y apuntes para una memoria del jazz en la Costa Vasca (c. 1917-1927)", Jazz-Hitz, 1, 2018, p. 76-77.

103 Soraluce y Villanueva: Bitz: boceto de comedia lírica en un acto y dos cuadros [manuscrito inédito], Rentería (Guipúzcoa), Archivo ERESBIL, Fondo 050/289.

104 https://www.eresbil.eus/web/uploads/archivosGeneradorWeb/Usandizaga-Fotografias/ereima_ K36-0045_c.jpg (consulta 7-6-2021). 
moras" acosan al "tonto" Juanito a ritmo de vals y tanguillo; una situación inexistente en la obra teatral original de Martínez Sierra (ilustración 5). El protagonista masculino de la escena (un enfermo mental, según los parámetros médicos de la época, y un sujeto amablemente cómico, dentro de la obra) rechaza sus solicitudes amorosas, alegando su "terror" a las mujeres. Para Salvador, dicho número era aceptable en una "zarzuela", pero no en un pretendido "drama lírico" 105 . Aun así, la escena sería replicada, con mayor refinamiento, en un coro de odaliscas de La llama. Significativamente, las bailarinas moras desaparecieron de la revisión de Las golondrinas que realizó el hermano del compositor, Ramón Usandizaga, a finales de la década siguiente, con el fin de convertir en ópera lo que en principio tenía un formato híbrido de zarzuela grande. Dicha revisión, estrenada en 1929, suprimió también el dúo del acto tercero en el que Cecilia seduce cínicamente al protagonista Puck ("él rendido y ella satisfecha y orgullosa, llevándole como una presa"106). De ese modo, la versión pretendidamente canónica (pero espuria) de la obra censuraba los dos únicos momentos en los que el deseo femenino aparecía escenificado de forma explícita y dominante ${ }^{107}$.

Frente a estas orgullosas exhibiciones de sensualidad femenina, llama la atención el decadente sino de los personajes masculinos de Usandizaga, probable reflejo de ansiedades personales ${ }^{108}$ y/o de época: en La llama, el príncipe galán muere acuchillado por una odalisca celosa, mientras que el protagonista de Las golondrinas -ataviado con una degradante indumentaria circense cuajada de bordados florales (ilustración 6) - se hunde en una psicosis esquizofrénica tras estrangular a su amante. Incluso en su supuestamente idílica "pastoral" Mendi-Mendiyan (1910), el tenor protagonista moría también acuchillado; en este caso, víctima de la hipermasculinidad negativa de su rival, Gaizto ("Malvado"): un desenlace que escandalizó a Francisco Gascue y otros críticos del País Vasco ${ }^{109}$. Por su parte, la presencia masculina no sobrepasa en Bitz la categoría de comparsa grotesca, en tanto que hombres-objeto de las protagonistas ${ }^{110}$.

\footnotetext{
${ }^{105}$ M. Salvador: "El drama lírico...", p. 5.

${ }^{106}$ Gregorio Martínez Sierra: Amanecer / Las golondrinas / El ideal, Madrid, Renacimiento, 1921, p. 177.

${ }^{107}$ Pese a que la moderna edición crítica de la obra restituye ambos pasajes musicales, la omisión del libreto zarzuelístico impide representar la obra en su versión original. José María y Ramón Usandizaga: Las golondrinas, Ramón Lazkano (ed.), Madrid, SGAE-ICCMU, 1999.

108 José Ignacio López de Luzuriaga: "José María Usandizaga, entre el folclore y el drama", Cuadernos de Música y Teatro, 2, 1987, pp. 86-89.

${ }^{109}$ Francisco Gascue: “Mendi-Mendiyan': ensayo de crítica musical”, Euskal-Erria: Revista Vascongada, 64, 1031, 30-4-1911, pp. 363-378.

110 Soraluce y Villanueva: Bitz...
} 


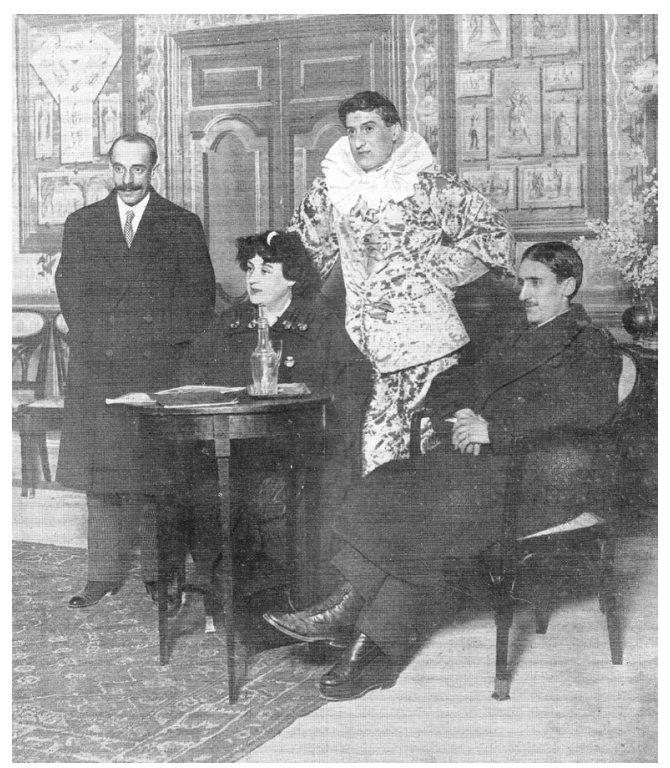

Ilustración 6. Gregorio Martínez Sierra, Luisa Vela, Emilio Sagi Barba (como Puck) y José María Usandizaga en el escenario de Las golondrinas. "Crónica gráfica: revelación de un gran músico”, Mundo Gráfico, 11-2-1914, p. 11

Aunque la creación de dichos caracteres podría atribuirse en exclusiva a sus libretistas (Martínez Sierra, José Power y "Soraluce yVillanueva", respectivamente), es probable que el siempre frágil Usandizaga, dependiente de continuos cuidados maternales y acechado por la enfermedad y la muerte desde la infancia, sintiese cierta simpatía o afinidad por semejantes héroes derrotados, de masculinidad vulnerable. Pese a su carácter risueño y entusiasta, es fácil imaginar las continuas frustraciones juveniles que su discapacidad fisica y sus prolongados períodos de postración febril tuvieron que acarrearle. Un claro reflejo de la melancolía provocada por sus forzadas curas de aislamiento en casas rurales lo encontramos sublimado en la voz de la protagonista de la cantata Umezurtza (La huérfana, 1913) ${ }^{111}$, sobre un texto redactado por el propio compositor: en ella, una muchacha se recluye dentro de su caserío para llorar su duelo en soledad, mientras sus jóvenes amigos, con su enamorado a la cabeza, se alejan en alegre romería ${ }^{112}$. En la biografia del músico, de hecho, no ha quedado constancia de ningún tipo de relación íntima o sentimental, si bien Arozamena apunta el inicio de un discreto galanteo epistolar con la jovencísima pianista zaragozana Pilar

\footnotetext{
${ }^{111}$ J. I. López de Luzuriaga: "José María...”, p. 87.

${ }^{112}$ José M. ${ }^{a}$ Usandizaga: Umezurtza: escena popular vascongada para solos y orquesta [partitura manuscrita], Rentería (Guipúzcoa), Archivo Vasco de la Música ERESBIL, Fondo A50/068.
} 
Bayona, en su último año de vida ${ }^{113}$. Como en los más mórbidos relatos decadentistas, una enfermedad maldita segó la vida del héroe "apenas consiguió su primer triunfo [...] en la flor de su edad" ${ }^{114}$.

\section{Conclusión}

En suma, la perspectiva de género aplicada al estudio de la figura y la obra de Usandizaga arroja interesantes y consistentes elementos para la comprensión de su contexto estético e ideológico, así como de la propia recepción de su legado. Por un lado, queda probado que el éxito de Las golondrinas fue acompañado de una campaña en prensa que glorificó al compositor como subyugador ídolo musical, con un perfil de adalid generacional y hasta de conquistador español, necesariamente masculino. Así, se observa una tendencia a subrayar su virilidad en cuanto que héroe nacional; en especial, pero no en exclusiva, desde medios conservadores.

Frente a esta visión, sus críticos detectaron en su obra ciertos elementos de alteridad que, de forma más o menos soterrada, podían cuestionar esa masculinidad idealizada. Dichos rasgos se alineaban dentro de las coordenadas de lo que entonces era considerado "modernismo" musical, y pueden resumirse en su cosmopolitismo mundano, poco atento a preocupaciones y urgencias identitarias de tipo nacionalista; una sonoridad de recargado preciosismo, y un manejo ecléctico de sus referentes estilísticos (impresionismo, verismo, wagnerismo, orientalismo) de discutida originalidad. Junto a ello, su vocación por seguir todas estas "modas" musicales con una actitud no iconoclasta, sino complaciente y comercial (o superficial, según sus mayores detractores), resultaba indigna de un artista intrépido, cuando no afeminada.

En esa atribución de marcas de género femeninas para deslegitimar una estética considerada "modernista", es curiosa la coincidencia de ciertos discursos finiseculares tradicionalistas (y aun clericales) con las voces más jóvenes que, como Salazar, consideraban este estilo ya anticuado o decadente. En concreto, llama la atención la recurrente comparación de semejante arte con los pretenciosos caprichos del atuendo a la moda. Además, la categorización de algunos elementos como "barrocos" o decorativos parece merecer una valoración especialmente negativa, presagiando la nueva simplicidad estética que acabaría extendiéndose en años venideros. Si, desde Viena, el arquitecto Adolf Loos ya había condenado el "ornamento" como un crimen insano, lúbrico y degenerado" ${ }^{115}$, dicho "delito" parecía

${ }^{113}$ J. M. Arozamena: Joshemari..., pp. 264-67.

${ }^{114}$ L. Villalba: José María..., p. 5.

${ }^{115}$ Adolf Loos: "Ornement et crime", Les Cahiers d'aujourd'hui, Marcel Ray (trad.), 5, 1913, pp. $247-$ 256. Editado en español como Ornamento y delito y otros escritos, Lourdes Ciriot, Pau Pérez (trads.), Barcelona, Gustavo Gili, 1972. 
más bien imputable a las mujeres, según sugerían los discursos misóginos de críticos españoles como Turina,Villar o Salazar; e impropio de un genio musical.

Por otro lado, era evidente que la figura enfermiza y aniñada de Usandizaga dificilmente podía ajustarse a los estereotipos de masculinidad heroica que se le presuponían. Tampoco su libretista (la feminista María Lejárraga, oculta bajo la firma de su marido Gregorio Martínez Sierra) encajaba en los roles de género normativos de aquella época. No es posible asegurar hasta qué punto estos factores personales influyeron en una valoración despectiva de su obra, pero algunos comentarios satíricos o maliciosos, e incluso determinadas caricaturas gráficas, permiten intuir la existencia de ciertos prejuicios descalificativos ad hominem. En cualquier caso, es claro que la ideología de género subyacente a los requisitos de masculinidad exigidos a cualquier obra maestra y a su creador genial tuvo que ejercer cierta incómoda presión sobre los autores. Quizá por ello su producción aparezca salpicada de significativas transgresiones de género, de filiación conscientemente decadentista.

Todas estas cuestiones trascienden la esfera de la privacidad meramente anecdótica al quedar encuadradas en debates estéticos y socio-culturales cuya sombra se extiende aún, en parte, hasta nuestros días. En efecto,la dialéctica entre virilidad y afeminamiento musicales que hemos rastreado en este trabajo puede considerarse un reflejo metafórico, a pequeña escala, de las tensiones que el ascenso social y laboral de la mujer, y la consiguiente reconfiguración de roles de género, estaban suscitando en aquel momento. En el terreno artístico y musical, creemos que responde también a un auténtico conflicto de cánones estéticos entre el Modernismo de tradición finisecular, deudor aún de paradigmas románticos, y el "arte nuevo" que se estaba fraguando durante los años de la contienda internacional, con su rechazo a cualquier sensibilidad de origen decimonónico. Como es sabido, este conflicto se resolvería en la década siguiente con llamadas generalizadas a una "vuelta al orden" y cierto espíritu neoclásico o de austera objetividad, cuyo máximo referente musical en España sería Manuel de Falla, consagrado por Salazar como campeón de la "música nueva".

A este respecto, es interesante recordar que, en términos más generales, Ortega y Gasset caracterizaría los valores éticos y estéticos de los años veinte como eminentemente masculinizados, en contraposición a un previo "afeminamiento", entendido como culto romántico a la feminidad ${ }^{116}$. De hecho, ya en 1923 el dictador Primo de Rivera había coincidido en reivindicar como "un movimiento de hombres" su golpe de estado contra el sistema parlamentario de la Restauración ${ }^{117}$. En tal contexto, obras de tan sofisticada

\footnotetext{
${ }^{116}$ José Ortega y Gasset: "Dinámica del tiempo: ¿masculino o femenino?", El Sol s 3-7-1927, p. 3.

117 "El que no siente la masculinidad completamente caracterizada, que espere en un rincón, sin perturbar, los días buenos que para la Patria preparamos". Diario de Barcelona, 13-9-1923, citado en N. Aresti: Masculinidades... p. 121.
} 
sensualidad como La llama o Bitz quedaron condenadas al olvido, mientras que Las golondrinas apenas pudo perpetuarse en el canon de la alta cultura musical española a fuerza de monumentalizarse en un formato puramente operístico, perdiendo su carácter híbrido genuino y reprimiendo sus trazos más ligeros e insinuantes. En consecuencia, desde entonces no es posible ver representada la obra maestra de Usandizaga según la concepción original de sus autores (que tanto deslumbró al público español de 1914); ni, mucho menos, aplaudir su exuberante coro de fingidas odaliscas seductoras, sistemáticamente suprimido, aún en la actualidad ${ }^{118}$.

\section{Bibliografia}

Aguilera Sastre, Juan: "María Lejárraga y el teatro de su época: la conquista de un público",

De literatura y música: estudios sobre María Martínez Sierra, Teresa Cascudo, María Palacios (eds.), Logroño, Instituto de Estudios Riojanos, 2014, pp. 63-93.

Ansorena, José Luis: “La alternativa de José M. ${ }^{a}$ Usandizaga", Las golondrinas, Madrid, Teatro Real, 1999, pp. 81-103.

Ara Torralba, Juan Carlos: "Modernismo y 98", Ocho calas en el pensamiento literario español, Eduardo E. Salas (ed.), Sevilla, Alfar, 2012, pp. 41-66.

ARESTr, Nerea: Médicos, donjuanes y mujeres modernas: los ideales de feminidad y masculinidad en el primer tercio del siglo XX, Bilbao, Universidad del País Vasco, 2001.

—: Masculinidades en tela de juicio, Madrid, Cátedra, 2010.

Arozamena, Jesús María de: Jesús Guridi: inventario de su vida y de su música, Madrid, Editora Nacional, 1967.

—: Joshemari Usandizaga y la bella época donostiarra, San Sebastián, Gráficas Izarra, 1969.

Aznar, Hugo; Menéndez AlzAmora, Manuel: "El éxito histórico de la Generación del 14", La Generación del 14: España ante su inacabada modernidad, Hugo Aznar, Elvira Alonso Romero, Manuel Menéndez Alzamora (eds.), Madrid, Plaza y Valdés, 2016, pp. 11-21.

Blanco, Alda: "El género como principio organizativo en la obra de María Martínez Sierra",

De literatura y música: estudios sobre María Martínez Sierra, Teresa Cascudo, María Palacios (eds.), Logroño, Instituto de Estudios Riojanos, 2014, pp. 15-34.

Burgos, Carmen de: Confidencias de artistas, Madrid, Juan Pueyo, s. f. [1916].

CARMOnA, Eugenio:"Vernáculo \& Moderno. Novecentismo y vanguardia en la colección del Museo de Bellas Artes de Bilbao", Novecentismo y Vanguardia (1910-1936) en la colección del Museo de Bellas Artes de Bilbao, Miren Alzuri (coord.), Bilbao, Museo de Bellas Artes, 2009, pp. 33-86.

CARREDANO, Consuelo:"Adolfo Salazar en España. Primeras incursiones en la crítica musical:la Revista Musical Hispanoamericana", Anales del Instituto de Investigaciones Estéticas, 26, 84, marzo 2004, pp. 119-144.

${ }^{118}$ Dicho número no fue representado en ninguna de las dos producciones escénicas más recientes de este título (Teatro Real, 1999; Teatro de la Zarzuela, 2016). Sí fue rodado en la adaptación televisiva que Juan de Orduña realizó para RTVE en 1967. Nunca ha sido incluido en los registros discográficos de la obra. 
Casares Rodicio, Emilio: “Fesser, Joaquín”, Diccionario de la música española e hispanoamericana, Emilio Casares Rodicio (dir.), Madrid, SGAE, 1998, vol. 5, p. 105.

- " "Crítica musical desde la segunda mitad del siglo XIX al siglo XX. Construcción historiográfica, debate estético, recepción y búsqueda del idioma propio a través de la crítica madrileña y barcelonesa", Música lírica y prensa en España (1868-1936): ópera, drama lírico y zarzuela, José Ignacio Suárez, Ramón Sobrino, María Encina Cortizo (eds.), Oviedo, Servicio de Publicaciones de la Universidad de Oviedo, 2018, pp. 37-65.

Cascudo, Teresa: "Los trabajos de Penélope musicóloga: musicología y feminismo entre 1974 y 1994”, Música y mujeres: género y poder, Marisa Manchado (ed.), Madrid, Horas y horas, 1998, pp. 179-190.

-: "Humor y pedagogía en las críticas de Miguel Salvador, el crítico buen aficionado de El Globo (1904-1913)", Los señores de la crítica: periodismo musical e ideología del modernismo en Madrid (1900-1950), Teresa Cascudo, María Palacios (eds.), Sevilla, Doble J, 2012, pp. 1-54.

- : "Adesso ci vuol altra cosa: primeros usos de los neologismos modernismo y modernista en el discurso periodístico sobre música en España (ca.1890-1910)”, Revista de Musicología, 40, 2 , 2017, pp. 513-42.

—: "Del ensueño a la realidad y de vuelta al ensueño: un estudio comparativo de Saltimbanquis, Aucells de pas y Las golondrinas", De literatura y música: estudios sobre María Martínez Sierra, Teresa Cascudo, María Palacios (eds.), Logroño, Instituto de Estudios Riojanos, 2014, pp. 135-155.

Castillo Martín, Marcia:“Mujeres de la Generación del 14: una generación de precursoras”, La Generación del 14: España ante su inacabada modernidad, Hugo Aznar, Elvira Alonso Romero, Manuel Menéndez Alzamora (eds.), Madrid, Plaza y Valdés, 2016, pp. 89-106.

Checa Puerta, Julio Enrique: "La actividad empresarial de Gregorio Martínez Sierra: una apuesta renovadora en la órbita del teatro comercial de preguerra", Anales de la Literatura Española Contemporánea, 23, 3, 1998, pp. 821-848.

—: "La mariposa de presa: algunas claves del Teatro de Arte", El Teatro de Arte. Libro de las Jornadas de zarzuela 2015, Alberto González Lapuente, Alberto Honrado Pinilla (eds.), Madrid, Fundación Jacinto e Inocencio Guerrero, 2016, pp. 36-55.

CuÚA, Isabel: Cuerpos de escándalo: celebridad femenina en el fin-de-siècle, Barcelona, Icaria, 2016.

—: "Las joyas de la Otero: los inicios del glamour en la escena teatral de fin de siglo", Miradas sobre el cuplé en España: identidades, contextos, artistas y repertorios, Enrique Encabo (ed.), Madrid, ICCMU, 2019, pp. 79-94.

EnCABo Fernández, Enrique: “Consuelo Vello, La Fornarina, (1884-1915): la divina erótica, la refinada sicalíptica”, Cultura de la seducción, Patricia Cifre Wibow, Manuel González de Ávila (coords.), Salamanca, Ediciones Universidad de Salamanca, 2014, pp. 251-258.

Frey, Stefan: "Going Global:The International Spread ofViennese Silver-Age Operetta", The Cambridge Companion to Operetta, Anastasia Belina, Derek B. Scott (eds.), Cambridge, Cambridge University Press, 2020, pp. 89-102.

GatTán-Salinas, Carmen; Murga-Castro, Idoia:"Las artes decorativas, un camino hacia la modernidad: Matilde Calvo Rodero y Victorina Durán”, Arte, Individuo y Sociedad, 33, 1, 2021, pp. 183-204. 
GonzÁLez de Durana, Javier: Las exposiciones de arte moderno de Bilbao: 1900-1910, Donostia-San Sebastián, BassaraiArte, 2007.

González Peña, María Luz: Música y músicos en la vida de María Lejárraga, Logroño, Instituto de Estudios Riojanos, 2009.

Henríquez Ureña, Max: Breve historia del modernismo, México / Buenos Aires, Fondo de Cultura Económica, 1954.

Herzovich, Guido: "Modernismo / Modernism”, Vocabulario de las filosofías occidentales: diccionario de los intraducibles, Barbara Cassin (dir.), México, Siglo XX Editores, 2018, vol. 2, pp. 1002-1010.

JASSA HARO, Ignacio: "Con un vals en la maleta: viaje y aclimatación de la opereta en España”, Cuadernos de Música Iberoamericana, 20, 2010, pp. 69-128.

Juan de la Encina y el arte de su tiempo (1883-1963), Museo de Bellas Artes de Bilbao / Museo Reina Sofia, 1998.

KirkPATRick, Susan: "Consideraciones sobre el género sexual en la configuración del hispanismo: una perspectiva estadounidense", Moenia: Revista Lucense de Lingüística \& Literatura, 4 , 1998, pp. 71-85.

—: Mujer, modernismo y vanguardia en España (1898-1931), Jacqueline Cruz (trad.), Madrid, Cátedra, 2003.

Lazkano, Ramón (ed.): José María y Ramón Usandizaga: Las golondrinas, Madrid, SGAE-ICCMU, 1999.

LERENA, Mario: “'Madrid brillante': modernismo y vanguardia de una década prodigiosa (c. 1910-1920)", El Teatro de Arte. Libro de las Jornadas de zarzuela 2015, Alberto González Lapuente, Alberto Honrado Pinilla (eds.), Madrid, Fundación Jacinto e Inocencio Guerrero, 2016, pp. 56-77.

—: “No me olvides': fuentes y apuntes para una memoria del jazz en la CostaVasca (c. 19171927)", Jazz-Hitz, 1, 2018, pp. 76-77.

—: "Usandizaga Soraluce, José María”, Auñamendi Eusko Entziklopedia, Eusko Ikaskuntza, 2021, http://aunamendi.eusko-ikaskuntza.eus/es/usandizaga-soraluce-jose-maria/ar-134577/ (Consulta 4-1-2021).

Loos, Adolf: Ornamento y delito y otros escritos, Lourdes Ciriot, Pau Pérez (trads.), Barcelona, Gustavo Gili, 1972.

LóPEZ De Luzuriaga, José Ignacio:"José María Usandizaga, entre el folclore y el drama”, Cuadernos de Música y Teatro, 2, 1987, pp. 86-89.

MaInER, José Carlos: 17 de diciembre de 1927: el triunfo de la literatura, Barcelona, Taurus, 2020.

Martínez Sierra, Gregorio: Amanecer / Las golondrinas / El ideal, Madrid, Renacimiento, 1921.

Martínez Sierra, María: Gregorio y yo: medio siglo de colaboración, México, Gandesa, 1953.

Montero Padilla, José: “Gregorio Martínez Sierra y su primera comedia”, Hesperia:Anuario de Filología Hispánica, 10, 2007, pp. 11-32.

Moreno Segarra, Nacho: Ladronas victorianas: cleptomanía y género en el origen de los grandes almacenes, s. 1., Antipersona, 2017.

MuÑoz, Matilde: De Música: ensayos de literatura y crítica, Madrid, El Imparcial, 1917. 
Palacios, María: La renovación musical en Madrid durante la dictadura de Primo de Rivera: el Grupo de los Ocho (1923-1931), Madrid, SEdeM, 2008.

Parralejo Masa, Francisco: El músico como intelectual:Adolfo Salazar y la creación del discurso de la vanguardia musical española (1914-1936), Madrid, SEdeM, 2019.

Serrano, Carlos; Salaün, Serge (eds.): Los felices años veinte: España, crisis y modernidad, Madrid, Marcial Pons, 2006.

Villalba Muñoz, Luis: José María Usandizaga, Madrid,Viuda de Pueyo, 1918.

VIllar, Rogelio: De música: cuestiones palpitantes, Madrid, Ricardo Rodríguez, 1917.

WebBer, Christopher: The Zarzuela Companion, Lanham, Maryland / Oxford, The Scarecrow Press Inc., 2002.

Recibido: 24-1-2021

Aceptado: 19-4-2021 